\title{
28 Research Soure \\ Geohazards Affecting Cultural Heritage \\ Monuments. A Complex Case Study From Romania
}

Dorina Camelia llies

Universitatea din Oradea

Tudor Caciora ( $\nabla$ tudor.caciora@yahoo.com )

Universitatea din Oradea

Grigore Vasile Herman

Universitatea din Oradea

Alexandru llies

Universitatea din Oradea

Madalina Ropa

Universitatea din Oradea

Stefan Baias

Universitatea din Oradea

Research article

Keywords: cultural heritage, geohazards, digitization, 3D modelling, photogrametry, conservation

Posted Date: May 28th, 2020

DOI: https://doi.org/10.21203/rs.3.rs-31190/v1

License: (c) (i) This work is licensed under a Creative Commons Attribution 4.0 International License.

Read Full License 


\section{Abstract}

The impact that geohazards have on cultural heritage requires continuous research in order to assess risks, prevention and conservation. This study has as the main research object, a uniquen monument in terms of its connection with the risk phenomena. It is about a wooden church historical monument from the village of Corbești, Romania, which was destroyed at the beginning of the tenth decade of the last century by a meteorological hazard, later reconstructed on a new site (in Oradea Municipality), and currently there is a risk of being affected by a geological hazard. The study focused on three main directions of research, namely: reconstructing the film of events, analyzing current risks and finding viable methods for future conservation and promotion. The methodology is based on extensive field research and the use of digital technologies. The results obtained confirmed the church's tendency to be affected by the emergence of a new risk phenomenon - landslides. In order to conserve and rebuild in case of need, the monument was digitized and a three-dimensional model of high accuracy was developed. This approach has the advantage of being low-cost, fast, non-invasive and providing large volumes of valuable information in the process of cultural heritage conservation.

\section{Introduction}

The cultural heritage represents an implementation of the customs, practices, values and artistic expressions (Nicu 2017a) of a community from the past, into our days. This bridge that connects the elements of the cultural heritage create between the past and the present (Indrie et al. 2019) is of indisputable value for the contemporary society, giving the citizen the idea of belonging to a certain society, of cultural identity. Their ability to interact with memory (Vecco 2010) is perhaps the main quality that ensures their persistence; over time, the people being aware of the value of these works so they tried to protect them. In order to fulfill our responsibility and the role of intermediaries in the process of protecting, preserving and transmitting the cultural heritage, it is fundamental to understand the dangers these elements are exposed to and how they can be evaluated and inhibited.

Due to the fragility and the need for authenticity, the cultural heritage is vulnerable to damage caused by anthropic hazards (expansion of localities, enlargement of the modern road network, accentuated soil erosion, pollution, vandalism, etc.) (Nicu 2017b; Agapiou et al. 2015; Hadjimitsis et al. 2013), as well as natural hazards (earthquakes, tsunamis, tornadoes, landslides, rock falls, floods, droughts, etc.) (Wang 2015; Lollino and Audisio 2006; Parisi and Augenti 2013; Nicu 2016; Badiali et al. 2018). If the first category of risks is easier to counteract in the future knowing the triggering factors, the predisposed areas and the necessary regulations; the second is even more dangerous, being characterized by unpredictability in space and time. The negative effects of natural hazards on the integrity of the population, economy and society are well known. A report by the Center for Research on the Epidemiology of Disasters (CRED 2019) states that in 2018 there were 315 natural hazards considered disasters, which affected over 68 million people, resulting in 11,804 deaths and material losses worth about $\$ 131.7$ 
billion. As regards the cultural heritage, and especially the immovable one, the consequences of these phenomena are often disastrous, being able to produce major damage or even the complete destruction of the goods, without being able to be restored (Nicu 2017a; Lanza 2003; Spennemann and Graham, 2007). But the occurrence of natural hazards does not only harm the elements that make up the cultural heritage of a region, there are also positive aspects of their activity. Examples include the extreme drought of the summer of 2003, which caused a record low flow of the Danube on the Romanian territory, discovering the submerged ruins of a Byzantine city; or the floods of 1971 from Dobrogea (Romania) that revealed a paleo-Christian basilica of the fourth century, in a very good state of conservation (Mara and Vlad 2008).

Geohazards are a separate category of risk phenomena, being defined as potentially harmful events for the population or the environment, directly related to the geological status and processes (Tomas and $\mathrm{Li}$ 2017; Wang et al. 2019). Most often, geohazards have as the main cause of triggering the natural phenomena and processes, but in some cases these can also occur as a result of human modeling interventions on the natural component (Zhu et al. 2017); thus, geohazards are individualized as geohazards of natural origin (landslides, earthquakes, tsunamis, volcanic eruptions, floods, rockfalls) and geohazard of anthropogenic origin (land subsidence, water contaminasion, extreme weather events due to atmosphere pollution etc.).

As previously shown, the safety of cultural heritage in the face of the hostility of nature is a delicate problem facing today's society (Frodella et al. 2020), involving many variables and unknown facts. But one thing is certain, namely the need to protect and preserve these living evidences of the past. This requires a better understanding of the risk factors and the initiation of diagnostic studies in order to implement measures to mitigate the risks and their consequences (Vojtekova and Vojtek, 2020). The technological progress of mankind has created many alternative methods to the traditional ones of risk assessment and conservation of cultural heritage elements (Pavlidis et al. 2007). These include GIS and digitization techniques, which have the advantage of being more efficient, less restrictive, cheap and noninvasive. Recent studies (Hadjmitsis et al. 2013; Iriarte et al. 2010; Agapio et al. 2015; Alexakis et al. 2013; Robinson et al. 2010) use GIS techniques to monitor in a systematic and integrated way the relation between the elements of cultural heritage and the support areal. Digitization as a conservation strategy is a relatively new concept that focuses on obtaining highly accurate geometric models for longterm conservation, assessing future evolution and reconstruction in case of disaster (Ruggiero et al. 2012). The viability of this approach is certified by the large number of studies (Madanan et al. 2018; Doulamis et al. 2012; Newell 2012; Marutoiu et al. 2017) that have used this as a working method for evaluating and protecting the cultural heritage. All these innovative techniques work together to create a virtual reality, facilitating the protection of the data obtained by digital storage, for future use; which should not be neglected for responsible custody.

\section{Wooden churches - a rich legacy of Romania}


Romania is a country with a rich cultural heritage, the Romanian people actively contributing along the historical stages in creating a cultural heritage with a strong touch of individuality and uniqueness. Among the most important remains are the wooden churches, as evidence of the craftsman's skill and of the Christian past of the Romanian people (Baias et al. 2015). The great significance and the central position that these constructions occupied in the life of the Romanians resides in the impressive number (1200) of wooden churches built before 1900, which are still preserved today (Droj et al. 2010).

The wooden churches in Romania have been extensively studied over time, from an architectural, cultural and spiritual value point of view (llieș et al. 2016), as well as from the point of the safety of the internal microclimate for the preservation of the monument and the health of the parishioners (llies et al. 2018a; Ilieș et al. 2018b; llieș et al. 2020). A less researched issue is the relationship between the wooden churches and the support areal. Due to their age and the inevitable deterioration of the organic materials out of which they are built, are prone to damage caused by the human activity and nature.

The wooden church with the dedication "Saints Archangel Michael and Gabriel"(Fig. 1), which is the subject of this study, was built at the beginning of the 17th century in Corbești Village, Bihor County and was painted on the inside in 1807 . It was done, like the great majority of wooden churches, by popular craftsmen and financed through the collective efforts of the local community. Since 1993, it has been moved to the Holy Cross Monastery in Oradea, where it is still located today. Starting with 2010, it is on the new list of historical monuments, being considered a building of local interest.

The past is the element that highlights this monument between the multitude of wooden churches that populate Romania and Bihor County; being closely related to natural hazards. Its evolution over time is influenced by a meteorological phenomenon of risk which is often assumed by both researchers and the general public that appears very rarely in Europe and has low intensity, a tornado (Antonescu et al. 2017). This event totally destroyed the church in the village of origin, Corbești, on July 3,1991, practically causing it to be moved and rebuilt at the Holy Cross Monastery, two years later. The move was seen as a new chance for this monument difficult to try to prevail, to transmit further the legacy of civilizations that now appear on the verge of extinction, more than ever. But due to the current position, at the foot of Oradea hills, an area whose geology is a factor favoring the initiation and evolution of the slope processes, the wooden church is threatened to be affected by a geohozard, the landslides.

Based on this consideration, the present study aims both to determine the conditions that favored the destruction of the church and to evaluate the geohazards risks to which the edifice is currently exposed. All these actions have as final aim the elaboration of preventive and reactive methods in order to conserve the place for a long period of time.

\section{Methodology}

The methodology for carrying out the present study followed three main research directions. The first two were focused on accumulating information related to natural hazards that affected or had the potential to affect the place of worship; while the latter, based on previous analyzes, has as its main purpose the 
preservation of the church through the use of digital methods frequently used in the study of cultural heritage.

\section{A. Meteorological hazard}

In order to prevent the possible effects of natural hazards on the wooden church for its preservation for a long period of time, the impact that the tornado of July 3, 1991 had on the future evolution of the monument cannot be neglected. In order to obtain the data regarding the conditions and the mode of production, the damage caused and the repercussions of the event, required an exhaustive consultation of specialized literature, archives and cartographic representations available. At the same time, field investigations were undertaken in order to reconstruct the thread of the events and carry out interviews with the eyewitnesses. Cartographic representations and expressive images were processed using ArcGis 10.6 and Adobe Photoshop CC 2015.5.

\section{B.Geohazards - The current risks}

The assessment of risks to which the church is currently exposed to was carried out through extensive field research, as well as using the territorial analysis techniques related to ArcGis 10.6 software. Following the examination it was found the tendency to be affected by the initiation of the landslides.

For a correct assessment of the risk, the map of the susceptibility index of the landslide zone (LSI) was developed in ArcGis 10.6 using the Frequency Ratio (FR) method. This method is based on the ratio between the probability of occurrence and the probability of non-coincidence (Lee and Evangelista 2005); the calculation mode for the landslides being the percentage of the area occupied by the slides compared to the percentage of the class of each parameter considered (Blaga et al. 2014; Solaimani et al. 2012; Pradhan and Lee 2010). Maps and orthophotoplans were used to establish the locations and mapping of the existing landslides, and further in the LSI creation, eight parameters (Fig. 2) were considered as determinants in triggering the landslides in the targeted area (Kalantar et al. 2018). The information needed to compile the parameters used for the FR method were extracted from Digital Elevation Models (DEM) derived from topographic plans and maps, orthophotoplans and thematic maps; all of which are complemented by field observations.

Considering that lithology is one of the most important triggering factors for landslides, a deep well drilling was dug to determine the underground deposits in the immediate vicinity of the monument, which confirmed the risk of triggering these phenomena. At the same time, the preliminary factors were identified and examined in the territory.

\section{Digitization for conservation and promotion}


Digitization is very important in the process of evaluation-preservation-restoration of the elements that make up the cultural heritage, and can also have attributions in the dissemination of knowledge. In the field of research related to cultural heritage and geohazards, with the advancement of digital technology, new methods are identified in order to conserve heritage assets, photogrammetry and 3D scanning (Alshawabkeh et al. 2020). By the three-dimensional models resulted, one can map, compare and study aspects of cultural heritage; these possibilities making them ideal for conservation and restoration (Scopigno et al. 2011; Akoglu et al. 2019).

The disadvantage of these practices is that the advanced processing tools often have a very high cost, and the field of cultural heritage research is often characterized by small budgets, low funds that are difficult to obtain. But 3D models with high resolution can also be made using cheap scanning devices, low cost or even open source software.

In order to obtain information, conservation and restoration in case of need of the wooden church within the Holy Cross Monastery in Oradea Municipality, it was considered to develop a three-dimensional model based on the photogrammetry method. In this case, this involved the semi-automatic generation of highly precise geometric details and textures, using 2D terrestrial images, processed only with cheap or free tools and software (Nicolae et al. 2014). In order to achieve this, four main steps were followed, as shown in Figure 3 (Themistocleous et al. 2016).

Due to the fact that the wooden church is an immovable object, located in the open air, it required a very careful planning of the photo acquisition process. The environment not offering controlled light, which could lead to a lack of texture and quality of the final model, it was decided to take pictures during daylight with mostly diffused natural light, as less direct as possible (Themistocleous et al. 2016). Thus the process of texturing mapping did not register any errors. At the same time, due to the vegetation and the surrounding constructions, the data acquisition was done with even greater attention, requiring in advance a field inspection to become familiar with the objective and calibration of the camera.

Step 2

The photos were taken using a Canon EOS-1D Mark III camera with a CMOS sensor of $28.1 \mathrm{x}$ $18.7 \mathrm{~mm}$. In order to have the best coverage of the object, terrestrial photographs were taken from different angles around the object (Fig. 4 - in blue), thus the coverage is almost complete. The camera was moved around the object keeping a relatively constant distance from it. In order to obtain an as accurate as possible model, the photographs thus obtained were first sorted by eliminating those that showed distortions, deformations or blur; as a result of this process, 186 viable photos are chosen for further processing.

\section{Step 3}

The processing of images implied introducing them into digital software in order to build the 3D model. For this, Meshroom 2019.2.0, CloudCompare and Agisoft Metashape 1.6.2 Professional Edition were 
used; the first two are open source programs, and the second one low cost. The processing step involved the fully automated reassembly of the object's shape by interpolating all the photographs in a reference space (Remondino 2011). In recreating the monument, the first step called Structure for Motion (SfM) (Ystikli 2007; Themistocleous et al. 2015) is of utmost importance because it analyzes the database and digitally reconstructs the position and orientation of the cameras around the object.

The automatic determination of the correspondences between the images has generated 190,359 individual points through matching algorithms (Fig. 4), forming the weak cloud of points on the basis of which the dense point cloud and the polygonal model were further constructed by meshing and texturing operations.

Step 4

For the final 3D cleaning and construction process, the model was imported in another open source program, MeshLab. Here all the surrounding objects that were not part of the formation of the monument were removed; being eliminated or blurred at the same time, any possible errors that might appear when the model is built, which affects its quality (Fig. 5).

The very good resolution of the photos taken allowed the large color details to be preserved. But in the end, the color projection on the wooden church was carefully checked and corrected in order to present the authentic aspect of the edifice as best as possible.

\section{Results And Discussions}

The three distinct sub-chapters in which the present chapter is fragmented practically represent analyzes on the past, present and future of a defining monument for the Romanian society. The investigations being centered on how the meteorological hazard from the past and the damage are caused, the assessment of the current geohazard risks, as well as the conservation methods. Thus, knowing the past, in the present the wooden church must be offered visible horizon in order to persist in the future.

\section{A. Meteorological hazard}

Meteorological hazards belong to the category of natural hazards and are divided into several categories according to the triggering speed. Tornadoes are perhaps among the most unpredictable fasttriggering weather phenomena. Precisely because of the speed of occurrence, the uncertainty in space and time, combined with the vulnerability of humans, the destructive potential of tornadoes is greatly amplified (Rauhala and Schultz 2009). Supercellular storms are the main factors accountable for the occurrence of most of the meteorological phenomena of risk; mostly all tornadoes from weak to violent being associated with these (Jones 2015; Spiridonov et al. 2010). This is also the case of the tornado of July 3, 1991 from Corbești, which was generated by a convective supercell responsible for producing a wide range of risk phenomena during the evolution in the region (Cristea 2004). 
On July 3, 1991, at 12 o'clock, about three hours before the event that took place in Corbești, the synoptic situation in Europe was characterized by the presence of a deep barric depression over the Balkan Peninsula, while the northeast of the continent was under the influence of a dorsal of the Azoric Anticyclone (Fig. 6). The positioning of Romania at the connexion between the North and East Azoric Anticyclone, characterized by warm air masses (over $20^{\circ} \mathrm{C}$ ) and the barric depression from southern Europe, with a cold air core $\left(8-10^{\circ} \mathrm{C}\right)$ (Fig. 7) (Cristea 2004), created the ideal premises for the production of risky weather phenomena.

Around 16 o'clock, on the radar map from that date, a convective radio echo with all the characteristics of a super cell (elliptical shape, cumulonimbus clouds strongly developed vertically, high reflectivity, etc.) appears well defined in the south of Oradea (Cristea 2004), moving at a speed of about $50 \mathrm{~km} / \mathrm{h}$ in the west-north-west direction. On the outskirts of Oradea there is also the village of Corbești, where the tornado appeared just before 16 o'clock. The tornado's trajectory was channeled on a valley that connects the villages of Corbești and Topa de Sus, leaving behind traces in which the effects were devastating, in one of them being the wooden church. The material losses following the event escaladed to 15 buildings destroyed, about 100 affected and over 1000 hectares of crops damaged and also registering a death.

In order to reconstruct the thread of the events, but also for a better understanding of the experiences of the locals, interviews were conducted in which the eyewitnesses participated. Thus, at the time of the event, most of the members of the local community were present at a funeral, on one of the hills bordering the village, at a considerable distance from the high intensity areas of the tornado. It is just sheer luck that the loss of human life is limited. Witnesses describe that before the tornado began, the sky "... had darkened, as if it were an eclipse or as it got dark ..." / ".. it darkened. As if it was night ..." / "... it got dark, like a kind of fog", and later on the phenomenon would be accompanied by a "... very strong sound", similar to the locals with the noise of a mill "... which grinds everything". The witnesses' statement leaves no room for interpretations on the typology of the meteorological phenomenon, the vast majority of them resembling "... a whirlwind ...", others even identifying it as a tornado.

Despite the short time it took, "... about 6-7 minutes" up to "... 10 minutes", the tornado left behind a distressing view of the village, with houses completely destroyed or uncovered and trees removed from the roots (Fig. 9, b and d). Of all, perhaps most had to suffer the wooden church historical monument of the village, the primal point, the core of spiritual and social life of any Christian settlement. This was practically destroyed completely, only the bell tower remaining standing in a precarious balance (Fig. 9, a and c). The remnants of the sanctuary were the main subject of a film made by representatives of the Episcopate of Bihor, about eight hours after the disaster, with the purpose of immortalizing the damage caused by this unexpected phenomenon.

The feeling of repulsion stemming from the superstitions of the locals, as well as their need for a more spacious place of worship, to inspire more security, led the old wooden church not being rehabilitated. After two years when it was torn down, the opportunity arose to relocate it to the Monastery of the Holy 
Cross in Oradea Municipality. Therefore, like a phoenix bird, the once destroyed church was reborn from its own ash to become the first church of the newly established monastery in Oradea.

\section{B. Geohazards - The current risks}

The monastery of the Holy Cross, being located at the foot of the Oradia Hills, an area whose geology is a factor favoring the installation and development of the slope processes, thus creating the risk that both the monastic settlement in general and the monumental wooden church in particular to be affected by a new risk factor - landslides.

The hills of Oradea are presented as a low hilly component, which does not exceed 300 meters (max. 292 $\mathrm{m}$ in the Osorheiu hill) from a morphometric point of view. They have the shape of long ridges oriented predominantly east-west, which make the transition from the hill area to the plain of Western Romania. In general, their lithology varies vertically from marly deposits belonging to the Pontian with massive and compact appearance in the subsoil, to sandy-clay complexes with thicknesses of a few meters at the top. Along with the lithological formation, the inclination of the layers in a cuesta type relief, the rich precipitations especially in the spring-summer period, the massive deforestation in the last decades and the overloading of the hills with constructions, they collaborate in creating favorable conditions for the initiation of landslides in the region. These phenomena occur with a very high frequency, especially on the hills on the right side of Crisul Repede River in the perimeter of Oradea Municipality; area where the wooden church is located.

The index map of the landslide susceptibility, based on local conditions, presents the spatial probability of producing new landslides in the targeted area. This is a useful tool for managing the geohazards induced by these phenomena, through higher land use planning, as well as better decisionmaking in predisposed areas (Pham et al. 2016). The interpretation of the map indicates that the area has a great tendency with regard to the appearance of these slope processes. Evidence in this regard is also the multitude of such risk phenomena that cover the hills of Oradea. The analysis on the four value categories of the susceptibility of the area to landslides reveals a relatively homogeneous distribution. The areas with the highest risk (31.9\%) have the largest extension, followed by those with medium risk (26.8\%), no risk $(20.8 \%)$ and small risk $(20.5 \%)$. The area with medium susceptibility where the wooden church is positioned, is guarded at the top by a sector with a large spatial terrain which is defined by a high susceptibility of landslides.

In order to determine the influence that the lithological composition has in determining the occurrence of these processes, in the immediate vicinity of the monument a drilling was done in order to determine the nature of the underground deposits. The interpretation of the results obtained after the drilling (Fig. 10), indicates that above a dense-looking marly substrate there are successive layers that consist of different types of clays and sands with a consistency of the soils from soft to hard, of about 20 meters thick. The alternation of the different layers with distinct cohesion leads to the evolution of soil degradation processes, facilitating the landslides. The balance of the slope in the immediate vicinity of the monument 
church is also affected by the aggressive anthropic intervention, taking place mainly in the last two decades. In this sense, it can be seen in figure 10 that the surfaces built with buildings and road alignments occupy a large area, being scattered throughout the hills. The risk is even higher as the area is constantly expanding in terms of construction, being a residential area in demand by the population of the municipality.

The field surveys in the immediate vicinity of the monastic settlement, reveal the presence of the activities preceding the landslides, sign that the slope is active and presents a risk of geohazards. In this sense we can mention deep cracks in the soil that decrease the cohesion of the material, cracks in the network of roads and sidewalks etc. In Figure 11 a we can see the inclination by about $8^{\circ}$ compared to the right angle of an electricity pole, in the direction of the material movement from the slope. The case is not an isolated one, this aspect being ascertained at most of the electricity poles in the area. At the same time, the cracks in the concrete post on which the church is located (Fig. 11b) denote an increased instability of the slope.

The occurrence of the harbinger phenomena of the landslides must be an alarm signal for the decision-making bodies regarding the risk situations. The integrated action of the factors set out above may affect the safety of the citizens and their property; and in particular to the security of a national heritage asset, the wooden church.

\section{Digitization for conservation and promotion}

The position of the wooden church, set exactly on a sliding wave of land, greatly limits the preventive measures that can be taken to preserve the monument. But, through digital techniques, reactive measures can be provided, which prove to be of great help in restoring the church in case if it will be affected by geohazards in the future. In this context, photogrammetry is shown to be a key factor in obtaining three-dimensional models of heritage buildings, which can reconstruct the destroyed or damaged heritage element, first digitally, and then in reality,

The 3D model (Fig. 12a) obtained from the processing of the field photographs depicting the wooden Church "Saints Archangel Michael and Gabriel", can stimulate the way the edifice is kept, viewed, registered and reconstructed in case of need.

This approach facilitates the virtual presentation of the areas affected by the slope movement, in order to make the best intervention and reconstruction decisions. Monitoring the effects of landslides on the church can be done by making such models periodically, and by comparison the most susceptible parts can be displayed.

The advantages of photogrammetry include not only the fact that it allows access to objects at great distances, but also supports their analysis. Photogrammetry thus becomes a viable alternative to direct field measurement of object dimensions; an analysis of this kind is presented in Figure 12b. Following the introduction of a reference measurement (performed in the field) and resetting the 
computing algorithms, the model allowed with centimeter precision the measurement of the wooden church dimensions. These data prove to be of great value in the event of geohazards. The information thus obtained can be made available to the restorers. Moreover, based on the model created, the destroyed parts of the church can be scanned and inserted into the system, and with the help of the MeshLab program, they can be digitally reassembled by manual repositioning at the original location. At the same time, the replica allows an approximate estimation of the volume of material needed to perform certain repair interventions.

The opportunities offered by the three-dimensional models practically minimize the possibility that the main features of the church will be modified again following a restoration process. A very advantageous situation considering that through a comparative analysis of the three photographs that make up Figure 1, it can be seen that over time, through successive repairs, the authentic aesthetic aspect of the monument has been obsolete.

The model achieved mostly reproduces the original features of the monument. But in order to conserve, recover and rehabilitate, the limits of the model created must also be taken into account, which in the present situation is given by the absence of crosses on the roof. This limit was obligatory due to the material it was made of and the color of crosses (silver sheeting), which having a very high light reflectivity it caused the loss of the contour and finally the inappropriate reconstruction. Due to this fact, those elements were eliminated from the final model.

This approach not only represents a cheap and non-invasive opportunity for the preservation and rehabilitation of the monument, but also constitutes a way of promoting geotourism, taking into account the important scientific-didactic and spiritual valences of the area. This place could represent a first complex stop from an urban geotourism trail of Oradea Municipality, Romania.

\section{Conclusions}

The evolution over time of the wooden church "Saints Archangel Michael and Gabriel" within the Holy Cross Monastery of Oradea is closely linked to natural hazards and especially with geohazards.

Presenting the way the tornado took place, which resulted in the destruction of the church, the archival images depicting the magnitude of the material losses and the rendering of the experiences of the locals, should not only represent a simple rediscovery of this tragic event in the history of the monument, but also a signal of alarm on the need for the protection and conservation of the cultural heritage. These actions are more important now after it has been proven through territorial analysis and field research that the wooden church is in an area prone to landslides, and the indications of the processes preceding these phenomena are already visible.

In this case, digital preservation seems to be the only solution. The 3D model created by the photogrammetry method based on overlapping 2D image, has the advantage of being able to be done with limited financial resources, also allowing for advanced analysis. Even if it does not provide effective protection against geohazards, three-dimensional models represent an important tool for reconstruction 
in case of need. By animating the way in which the cultural heritage is researched, organized, visualized and conserved, it must represent a fundamental approach for research in the field.

\section{Declarations}

\section{Acknowledgments}

The current research was made possible by the equally strong scientific involvement of all the authors concerned, who wish to acknowledge the support of the Grant PN-III-P1-1.2-PCCDI-2017-0686.

\section{Author contributions}

All the authors contributed both to the data collection and to their interpretation, as well as to the writing of the article.

\section{Competing financial interests}

The authors declare no competing financial interests.

\section{References}

1. Agapiou A, Lysandrou V, Alexakis DD, Themistocleous K, Cuca B, Argyriou A, Argyriou B, Sarris N, Hadjimitsis DG. Cultural heritage management and monitoring using remote sensing data and GIS: The case study of Paphos area, Cyprus. Computers. Environment and Urban Systems. 2015;54:230239.

2. Akoglu KG, Kotoula E, Simon S. Combined use of ultrasonic pulse velocity (UPV) testing and digitaltechnologies: A model for long-term condition monitoring memorialsin historic Grove Street Cemetery, New Haven. Journal of Cultural Heritage. 2019;41:84-95.

3. Alexakis DD, Agapiou A, Tzouvaras M, Themistocleous K, Neocleous K, Michaelides S, Hadjimitsis DG. Integrated use of GIS and remote sensing for monitoring landslides in transportation pavements: the case study of Paphos area in Cyprus. Natural Hazards. 2013;72(1):119-141.

4. Alshawabkeh Y, El-Khalili M, Almasri E, Bala'awi F, Al-Massarweh. Heritage documentation using laser scanner and photogrammetry. The case study of Qasr Al-Abidit, Jordan. Digital Applications in Archaeology and Cultural Heritage. 2020;16:e00133.

5. Antonescu B, Schultz DM, Holzer A, Groenemeijer P. Tornadoes in Europe: An Underestimated Threat. Bulletin of the American Meteorological Society. 2015;98(4):713-728.

6. Badiali F, llieș DC, Castaldini D. A tale of a city, through its urban landscape and cultural heritage in the heart of Europe: The case study of Oradea City (Romania). GeoJournal of Tourism and Geosites. 2018;21(1):88-102. 
7. Baias S, Gozner M, Herman GV, Măduța F. Typology of wooden churches in the drainage basins of Mureș and Arieș, Alba County. Analele Universității din Oradea, Seria Geografie. 2015;25(2):221-233.

8. Blaga L, Josan N, llieș DC. Relieful și Amenajarea Teritoriului. Editura Universității din Oradea, Oradea; 2014.

9. CRED. Natural disasters 2018. 2019. https://cred.be/publications. Accessed 11 March 2020.

10. Cristea M. Riscurile climatice din bazinul hidrografic al Crisurilor. Editura Abaddaba, Oradea; 2004.

11. Davies-Jones R. A review of supercell and tornado dynamics. Atmospheric Research. 2015;158159:274-291.

12. Doulamis N, Doulamis A, loannidis C, Klein M, loannides M. Modelling of Static and Moving Objects: Digitizing Tangible and Intangible Cultural Heritage. Mixed Reality and Gamification for Cultural Heritage. 2017;567-589.

13. Droj G, Mancia A, Droj L. Biserici de lemn în bazinul Crișului Repede. Editura Duran's, Oradea; 2010.

14. Frodella W, Elashvili M, Spizzichino D, Gigli G, Adikashili L, Vacheishvili N, Kirkitadze G, Nadaraia A, Margottini C, Casagli N. Combining InfraRed Thermography and UAV Digital Photogrammetry for the Protection and Conservation of Rupestrian Cultural Heritage Sites in Georgia: A Methodological Application. Remote Sensing. 2020;12(5):892.

15. Hadjimitsis D, Agapiou A, Alexakis D, Sarris A. Exploring natural and anthropogenic risk for cultural heritage in Cyprus using remote sensing and GIS. International Journal of Digital Earth. 2013;6(2):115-142.

16. Ilieș A, Wendt J, llieș DC, Herman GV, Ilieș M, Deac A. The patrimony of wooden churches, built between 1531 and 2015, in the Land of Maramureș, Romania. Journal of Maps. 2016;12:597-602.

17. Ilieș DC, Herman GV, Caciora T, Ilieș A, Indrie L, Wendt J, Axinte A, Diombera M, Lite C, Berdenov Z, Albu A. Considerations Regarding the Research for the Conservation of Heritage Textiles in Romania. In: Textile Industry and Waste, IntechOpen. doi: http://dx.doi.org/10.5772/intechopen.91393; 2020.

18. Ilieș DC, Onet A, Wendt J, Ilieș M, Baias S, Herman G. Study on microbial and fungal contamination of air and wooden surfaces inside of a historical Church from Romania. Journal of Environmental Biology. 2018a;39(6): 980-984.

19. Ilieș DC, Onet A, Marcu F, Gaceu O, Timar A, Baias S, Ilies A, Herman GV, Costea M, Tepelea M, Josan I, Wendt J. Investigations on air quality in the historic wooden church in Oradea city, Romania. Environmental Engineering and Management Journal. 2018b;17(11):2731-2739.

20. Indrie L, Oana D, llieș M, Ilieș DC, Lincu A, Ilieș A, Baias Ș, Herman GV, Oneț A, Costea M, Marcu F, Burtă L, Oana I. Indoor air quality of museums and conservation of textiles art works. Case study: Salacea Museum House, Romania. Industria Textila Journal. 2019;70(1):88-93.

21. Iriarte E, Sánchez MÁ, Foyo A, Tomillo C. Geological risk assessment for cultural heritage conservation in karstic caves. Journal of Cultural Heritage. 2010;11(3):250-258.

22. Kalantar B, Pradhan B, Naghibi SA, Motevalli A, Mansor S. Assessment of the effects of training data selection on the landslide susceptibility mapping: a comparison between support vector machine 
(SVM), logistic regression (LR) and artificial neural networks (ANN). Geomatics, Natural Hazards and Risk. 2018;9(1):49-69.

23. Lanza SG. Flood hazard threat on cultural heritage in the town of Genoa (Italy). Journal of Cultural Heritage. 2003;4(3):159-167.

24. Lee S, Evangelista DG. Landslide Susceptibility Mapping using Probability and Statistics Models in Baguio City, Philippines.

https://pdfs.semanticscholar.org/bf59/147f106045fce8241d76fd6f1e2479015086.pdf; 2005.

25. Lollino G, Audisio C. UNESCO World Heritage sites in Italy affected by geological problems, specifically landslide and flood hazard. Landslides. 2006;3(4):311-321.

26. Madanan M, Hussain N, Khaliq AA. A study of the digitization process to preserve the culture and heritage of a civilization using natural language processing and it's impact on the social, economic and scientific aspects. Journal of Theoretical and Applied Information Technology. 2018;96(16):5550-5568.

27. Mara S, Vlad SN.Positive efects of natural hazards on cultural heritage in Romania. Geografia Fisica e Dinamica Quaternaria. 2008;31:181-186.

28. Marutoiu C, Bratu I, Nemes OF, Dit I-I, Comes R, Tanaselia C, Falamas A, Miclaus M, Marutoiu VC, Moraru R. Instrumental analysis of materials and topology of the Imperial Gates belonging to the Apahida wooden church, Cluj County. Vibrational Spectroscopy. 2017;89:131-136.

29. Newell J. Old objects, new media: Historical collections, digitization and affect. Journal of Material Culture. 2012;17(3):287-306.

30. Nicolae C, Nocerino E, Menna F, Remondino F. Photogrammetry applied to Problematic artefacts. Int. Arch. Photogramm. Remote Sens. Spatial Inf. Sci XL-5:451-456.

https://doi.org/10.5194/isprsarchives-XL-5-451-2014; 2014.

31. Nicu IC. Cultural heritage assessment and vulnerability using Analytic Hierarchy Process and Geographic Information Systems (Valea Oii catchment, North-eastern Romania). An approach to historical maps. International Journal of Disaster Risk Reduction. 2016;20:103-111.

32. Nicu IC. Natural hazards - A threat for immovable cultural heritage. A review. International Journal of Conservation Science. 2017a;8:375-388.

33. Nicu IC. Tracking natural and anthropic risks from historical maps as a tool for cultural heritage assessment: a case study. Environmental Earth Sciences. 2017b;76(9):330.

34. Parisi F, Augenti N. Earthquake damages to cultural heritage constructions and simplified assessment of artworks. Engineering Failure Analysis. 2013;34:735-760.

35. Pavlidis G, Koutsoudis A, Arnaoutoglou F, Tsioukas V, Chamzas C. Methods for 3D digitization of Cultural Heritage. Journal of Cultural Heritage. 2007;8(1):93-98.

36. Pham BT, Pradhan B, Tien Bui D, Prakash I, Dholakia MB. A comparative study of different machine learning methods for landslide susceptibility assessment: A case study of Uttarakhand area (India). Environmental Modelling \& Software. 2016;84:240-250. 
37. Pradhan B, Lee S. Landslide susceptibility assessment and factor effect analysis: backpropagation artificial neural networks and their comparison with frequency ratio and bivariate logistic regression modelling. Environmental Modelling \& Software. 2010;25(6):747-759.

38. Rauhala J, Schultz DM. Severe thunderstorm and tornado warnings in Europe. Atmospheric Research. 2009;93(1-3):369-380.

39. Remondino F. Heritage Recording and 3D Modeling with Photogrammetry and 3D Scanning. Remote Sensing. 2011;3(6):1104-1138.

40. Robinson MH, Alexander CR, Jackson CW, McCabe CP, Crass D. Threatened archaeological, historic, and cultural resources of the Georgia Coast: Identification, prioritization and management using GIS technology. Geoarchaeology. 2010;25(3):312-326.

41. Ruggiero C, Gallo A, Lio A, Zappani A, Fortunato G, Muzzupappa M. An Integrated Methodology for the Digitization, Survey and Visualization of Santa Maria Patirion's Church. International Journal of Heritage in the Digital Era. 2012;1(1):21-26.

42. Scopigno R, Callieri M, Cignoni P, Corsini M, Dellepiane M, Ponchio F, Ranzuglia G. 3D Models for Cultural Heritage: Beyond Plain Visualization. Computer. 2011;44(7):48-55.

43. Solaimani K, Mousavi SZ, Kavian A. Landslide susceptibility mapping based on frequency ratio and logistic regression models. Arabian Journal of Geosciences. 2012;6(7):2557-2569.

44. Spennemann DHR, Graham K. The importance of heritage preservation in natural disaster situations. International Journal of Risk Assessment and Management. 2007;7(6/7):993.

45. Spiridonov V, Dimitrovski Z, Curic M. A Three-Dimensional Simulation of Supercell Convective Storm. Advances in Meteorology. 2010;1-15.

46. Themistocleous K, Agapiou A, Hadjimitsis D. Experiencing Cultural Heritage Sites Using 3D Modeling for the Visually Impaired. 2016;10059:171-177.

47. Themistocleous K, loannides M, Agapiou A, Hadjimitsis DG. The methodology of documenting cultural heritage sites using photogrammetry, UAV, and 3D printing techniques: the case study of Asinou Church in Cyprus. Third International Conference on Remote Sensing and Geoinformation of the Environment (RSCy2015). doi:10.1117/12.2195626; 2015.

48. Tomas R, Li Z. Earth Observations for Geohazards: Present and Future Challenges. Remote Sensing. 2017;9(3):194.

49. Vecco M. A definition of cultural heritage: From the tangible to the intangible. Journal of Cultural Heritage. 2010;11(3):321-324.

50. Vojtekova J, Vojtek M. Assessment of landslide susceptibility at a local spatial scale applying the multi-criteria analysis and GIS: a case study from Slovakia. Geomatics, Natural Hazards and Risk. 2020;11(1):131-148.

51. Wang G, Ye W, Lv Y. Loess Geoheritage and Geohazard Protective Measures at Luochuan Loess National Geopark in NW China. Geoheritage. doi:10.1007/s12371-019-00354-5; 2019. 
52. Wang JJ. Flood risk maps to cultural heritage: Measures and process. Journal of Cultural Heritage. 2015;16(2):210-220.

53. Yastikli N. Documentation of cultural heritage using digital photogrammetry and laser scanning. Journal of Cultural Heritage. 2007;8(4):423-427.

54. Zhu H-H, Shi B, Zhang CC. FBG-Based Monitoring of Geohazards: Current Status and Trends. Sensors. 2017;17(3):452.

\section{Figures}

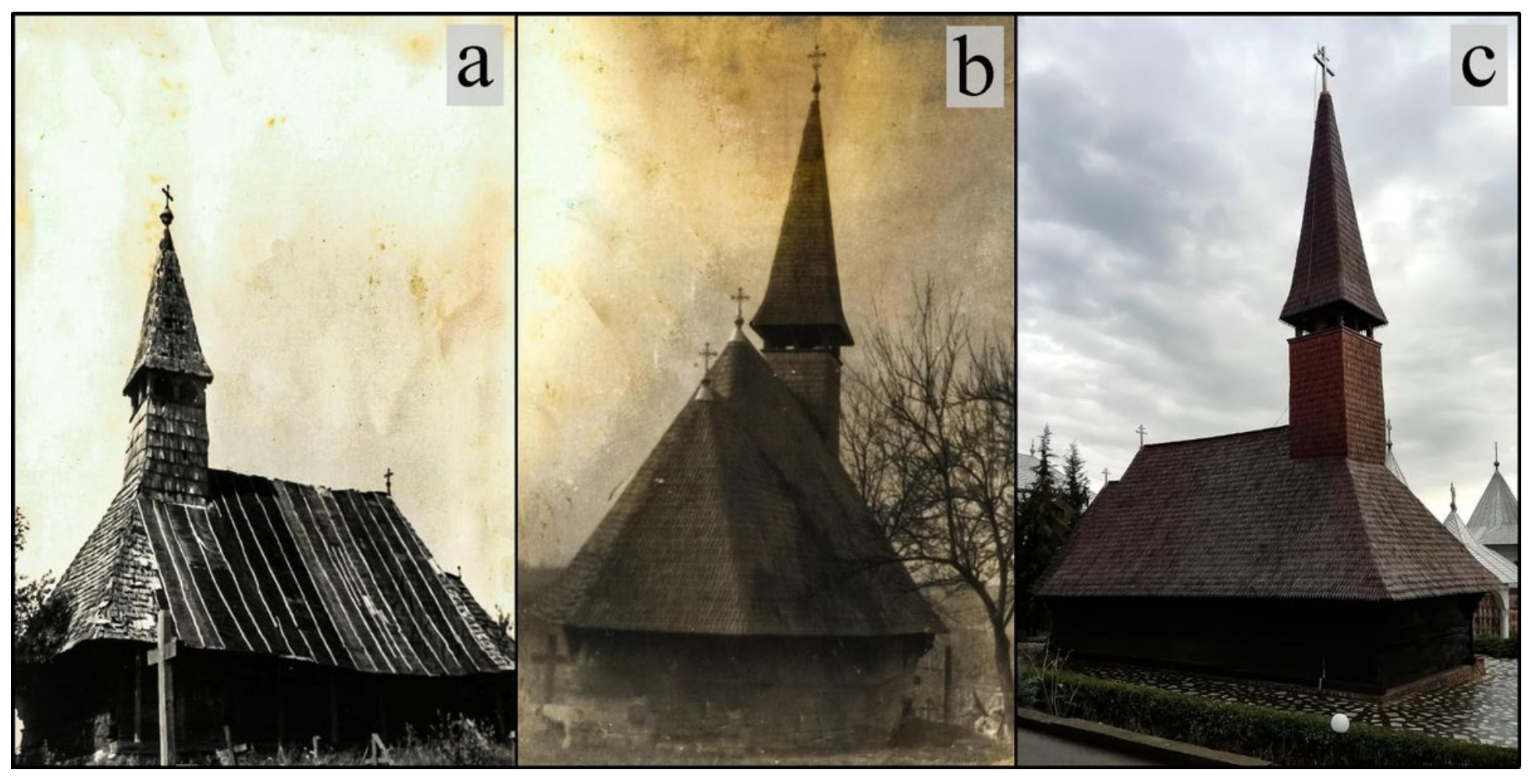

\section{Figure 1}

Wooden church with the dedication "Saints Archangel Michael and Gabriel" a.The church from Corbești village in a photo from 1971; b. The church from Corbești village in a photo from the ' 80 s; $c$. The wooden church within The Holy Cross Monastery in a photo from 2019 


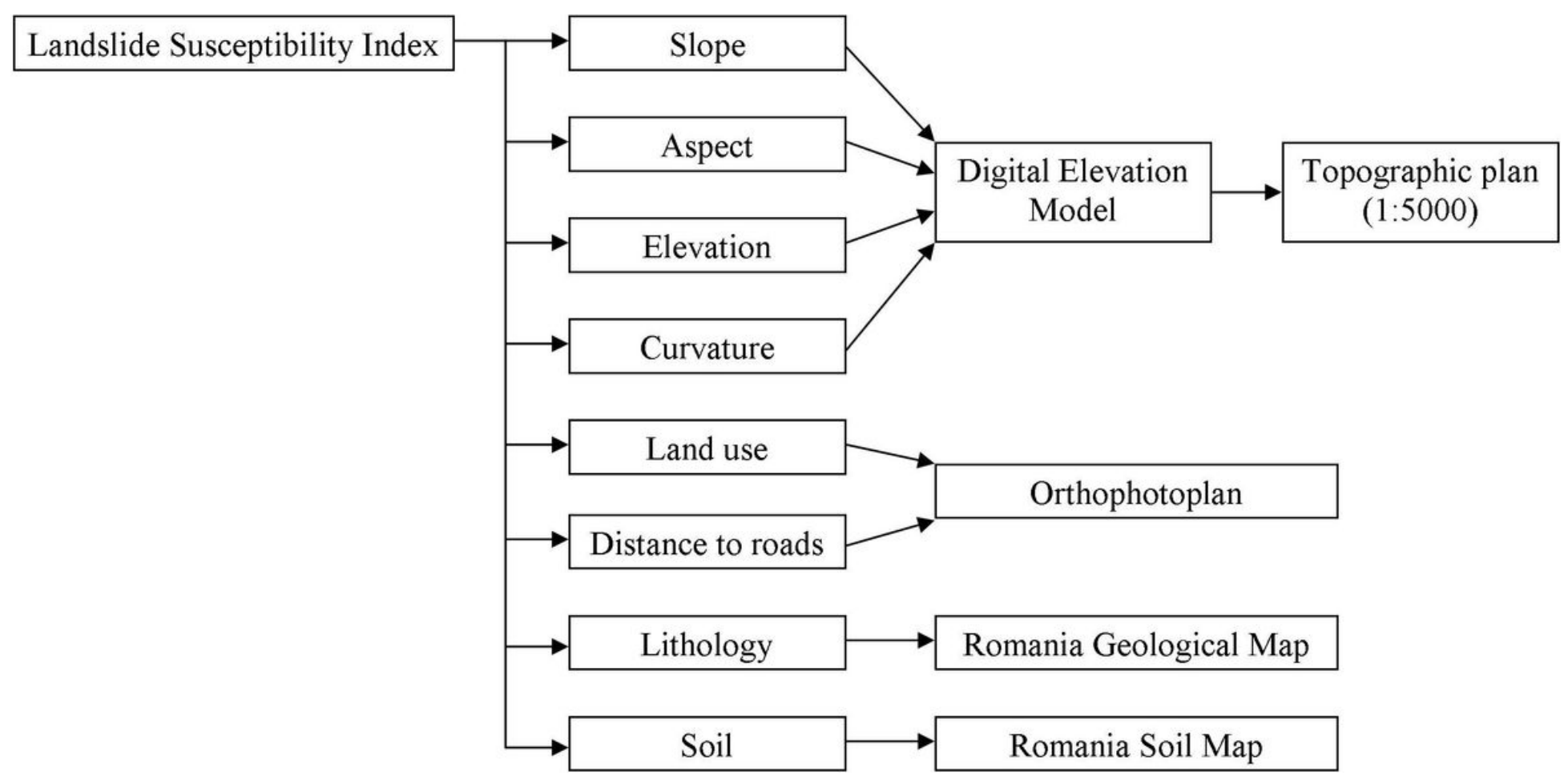

Figure 2

The parameters considered for the realization of the Landslide Susceptibility Index (LSI)

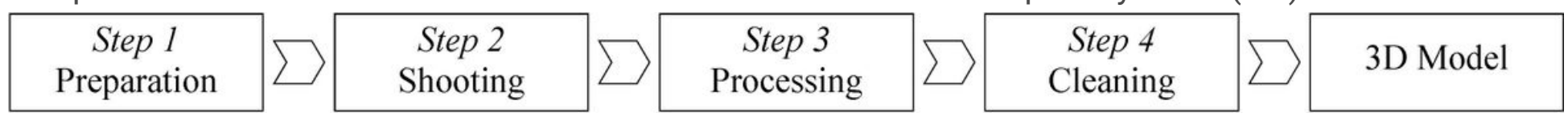

\section{Figure 3}

Methodology for obtaining the three-dimensional model 
Perspective $30^{\circ}$

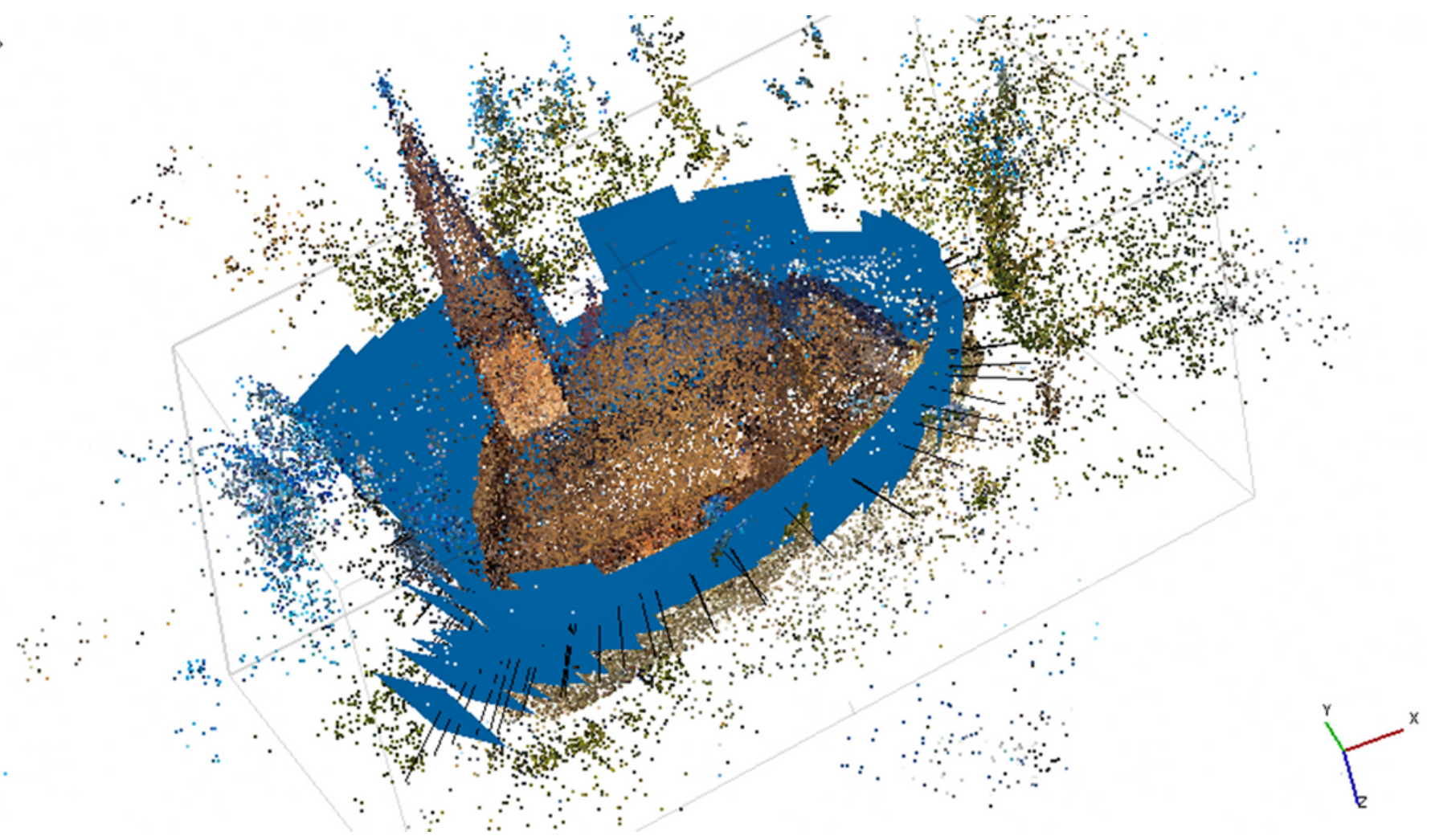

Figure 4

The weak cloud of points and the position and orientation of the camera at the time of taking each photo (in blue)
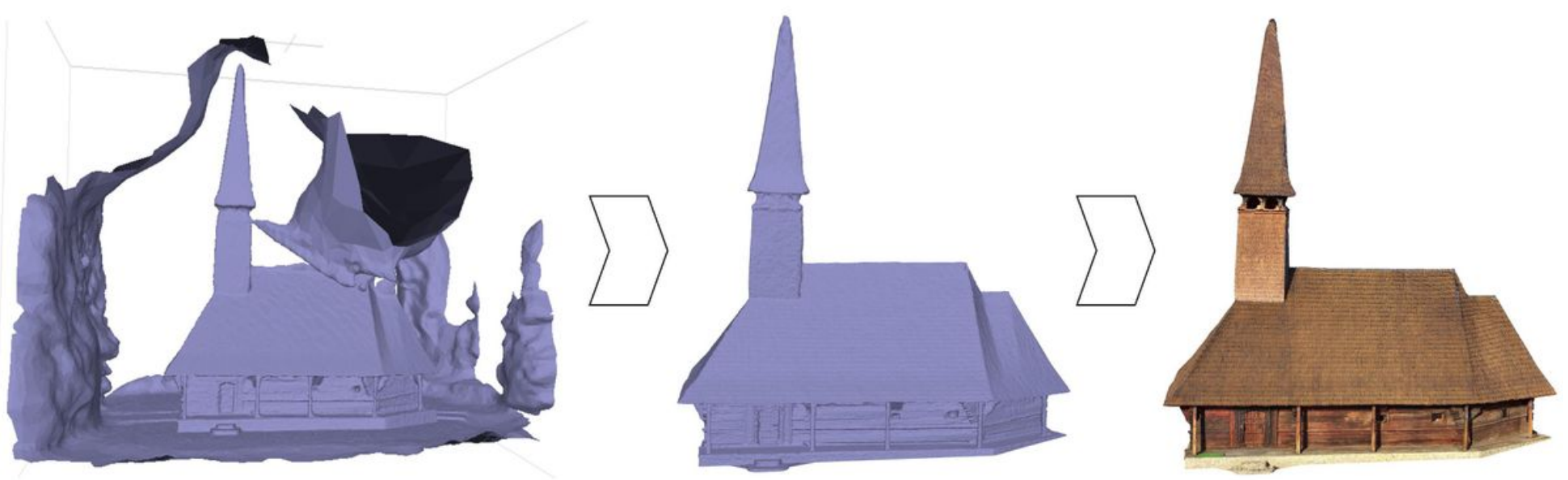

Figure 5

The process of cleaning and making the final three-dimensional model 


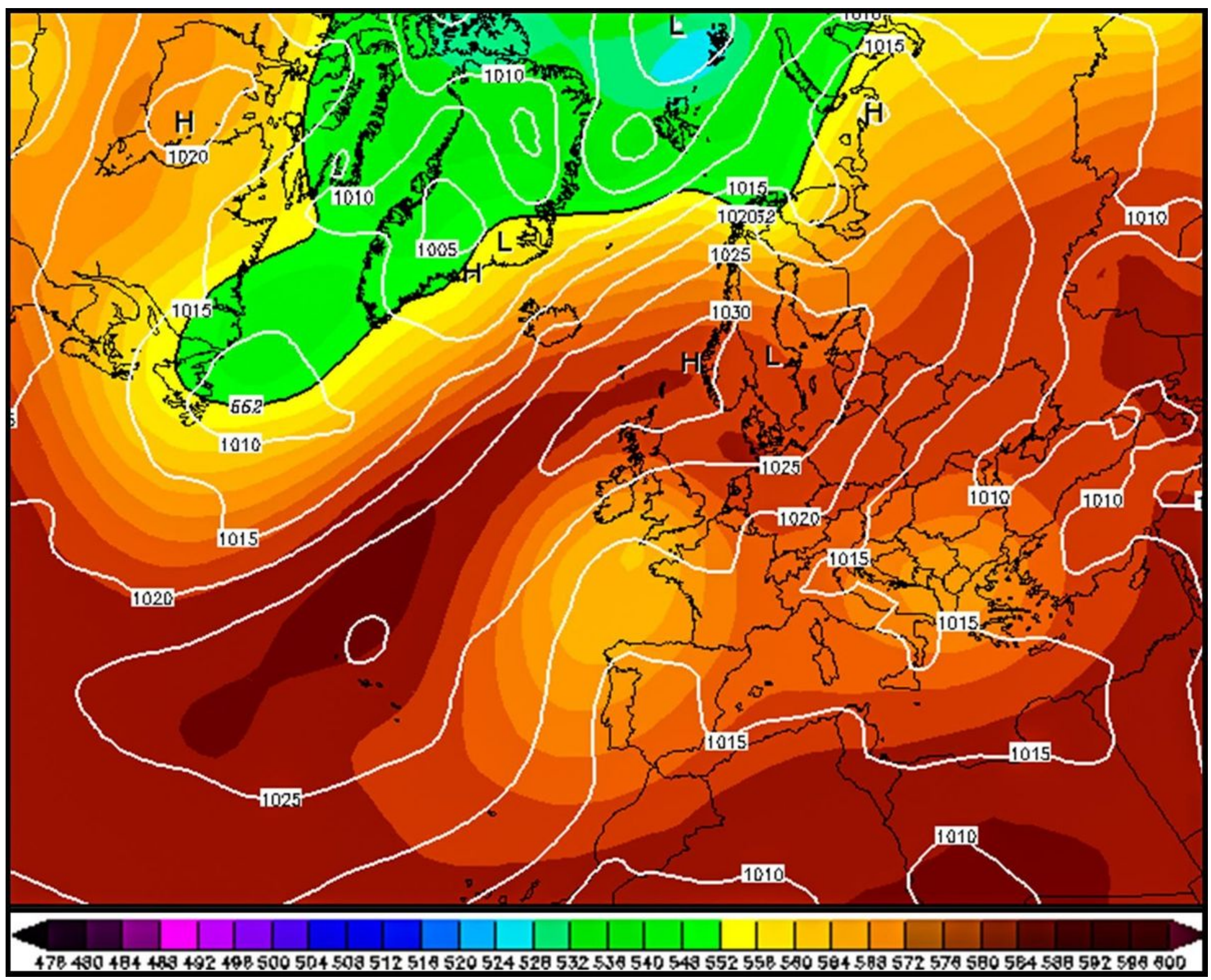

Figure 6

500 hPa geopotential at 12:00 UTC on 3 July 1991 (source: www.wetterzentrale.de) 


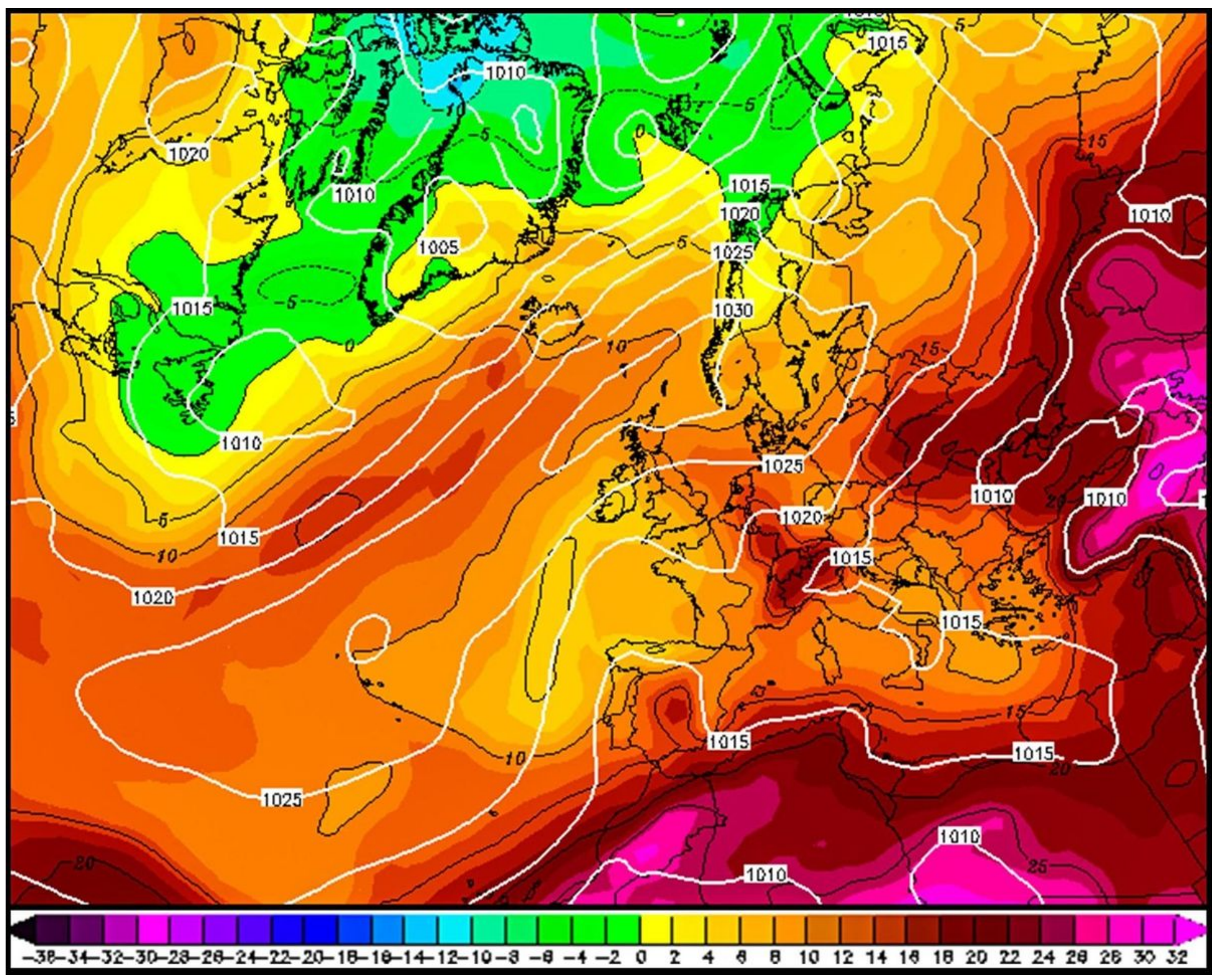

Figure 7

Temperature at $850 \mathrm{hPa}$ at 12:00 UTC on 3 July 1991 (source: www.wetterzentrale.de) 


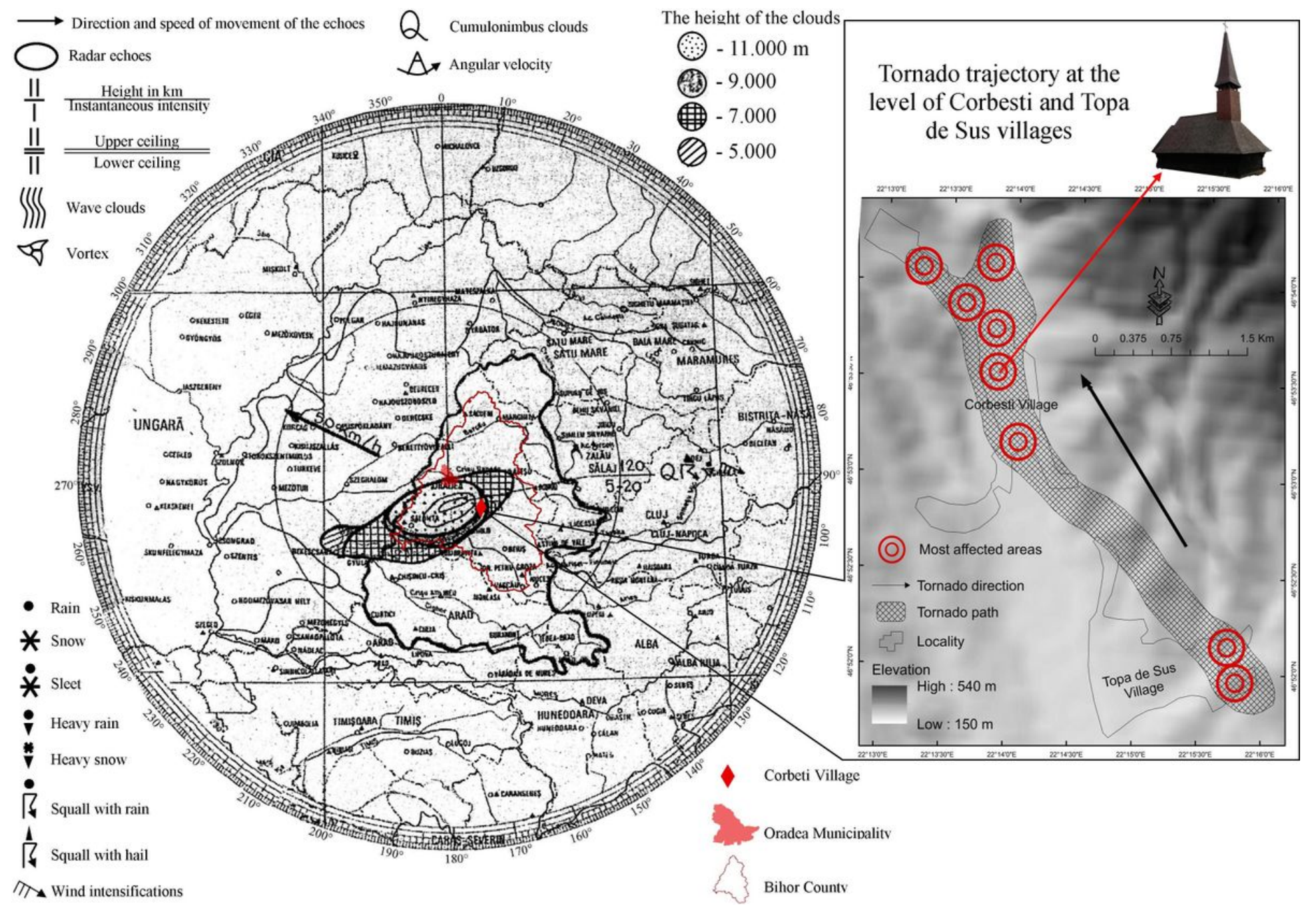

Figure 8

The radar map from July 3, 1991, 4 pm and tornado trajectory at the level of Corbesti and Topa de Sus villages (processed with improvements after Cristea, 2004) 


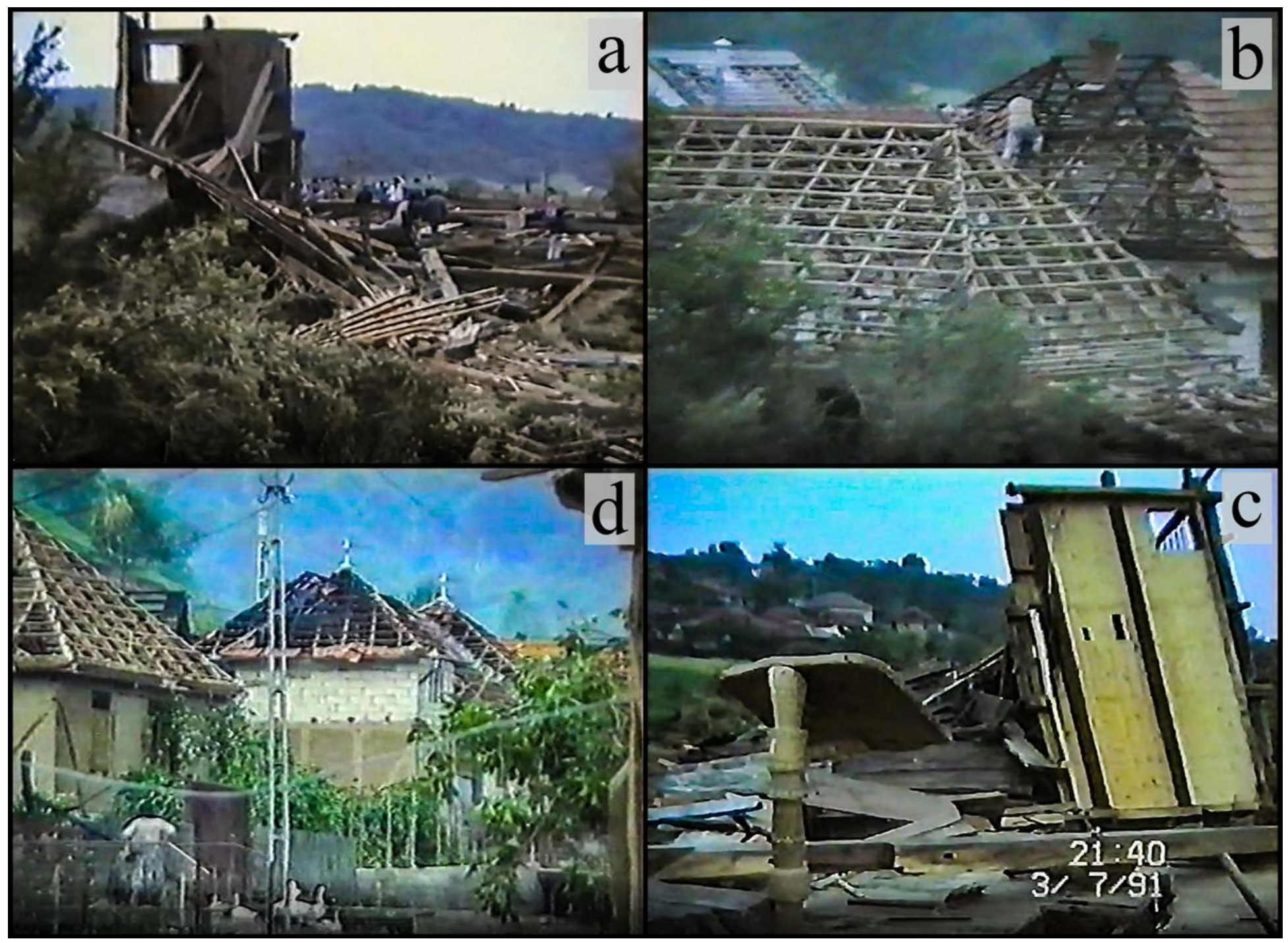

Figure 9

The material losses caused by the tornado in the village of Corbesti a and $\mathrm{c}$. The remains of the wooden church; $b$ and $d$. The damage created to the homes of the villagers 


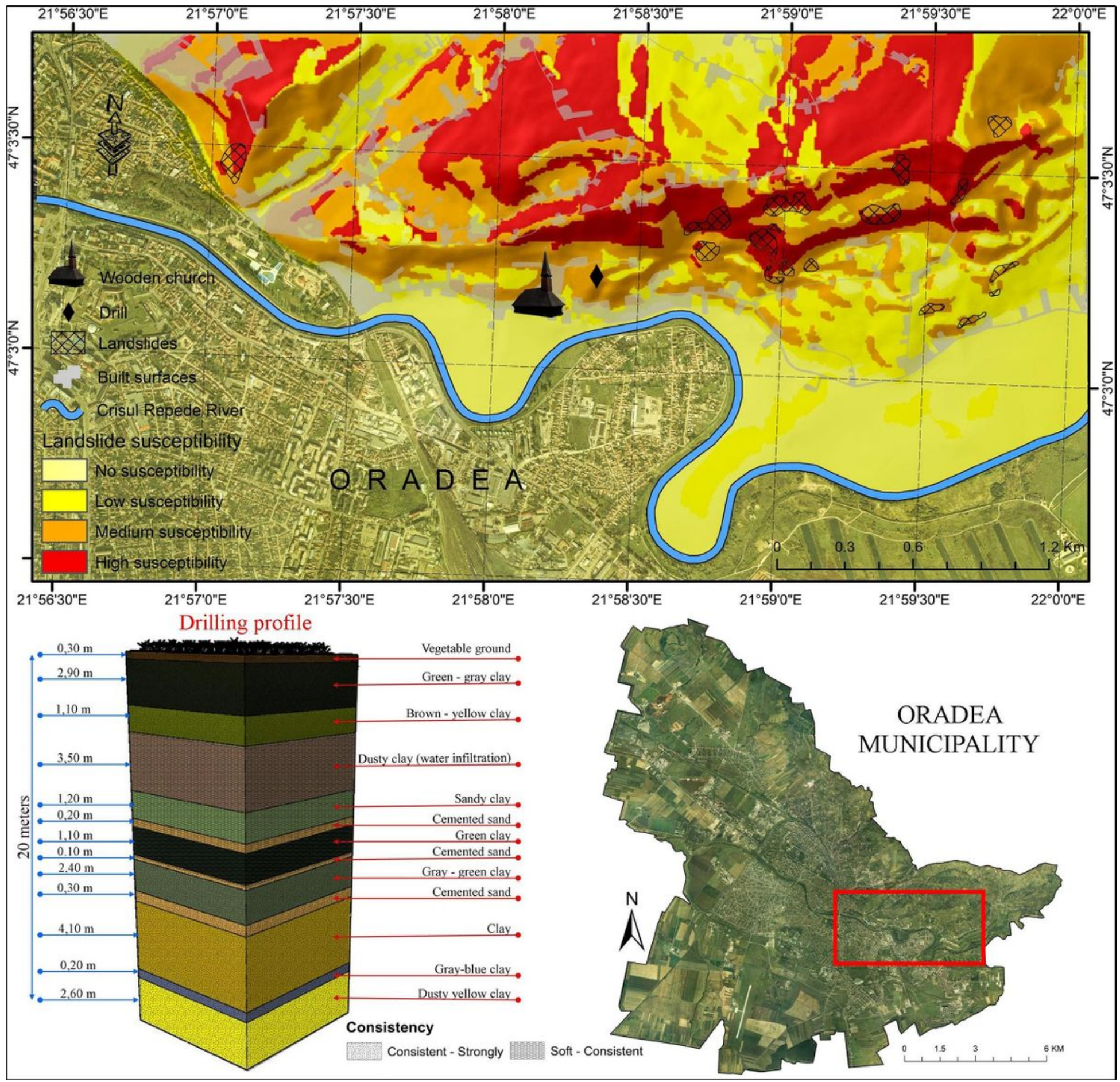

Figure 10

Susceptibility of the area to landslides expressed by LSI 


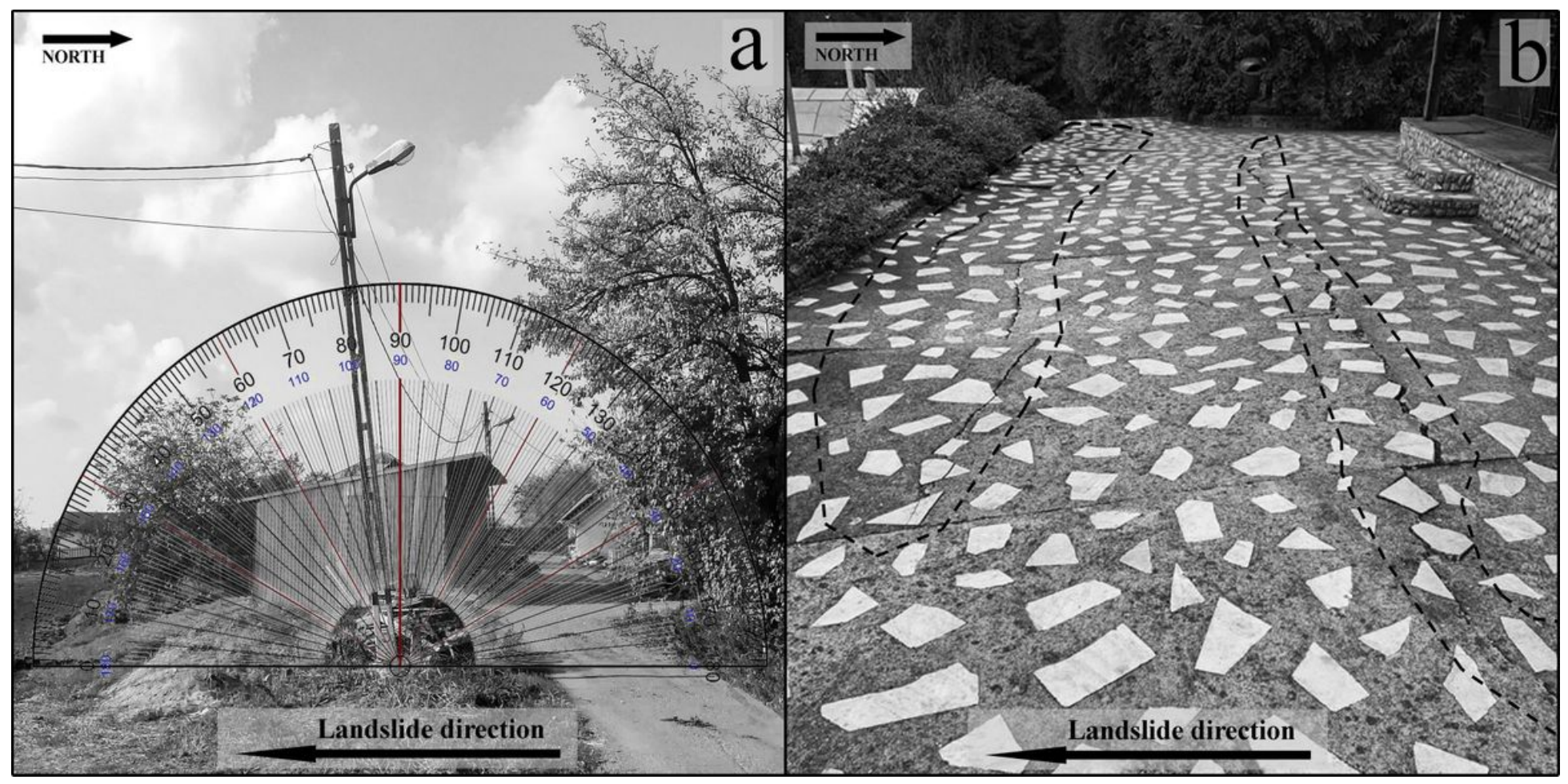

\section{Figure 11}

Preliminary processes of landslides in the vicinity of the monument a. Inclination of an electricity pillar in the direction of the material displacement; b. cracks in the plateau on which the church is located
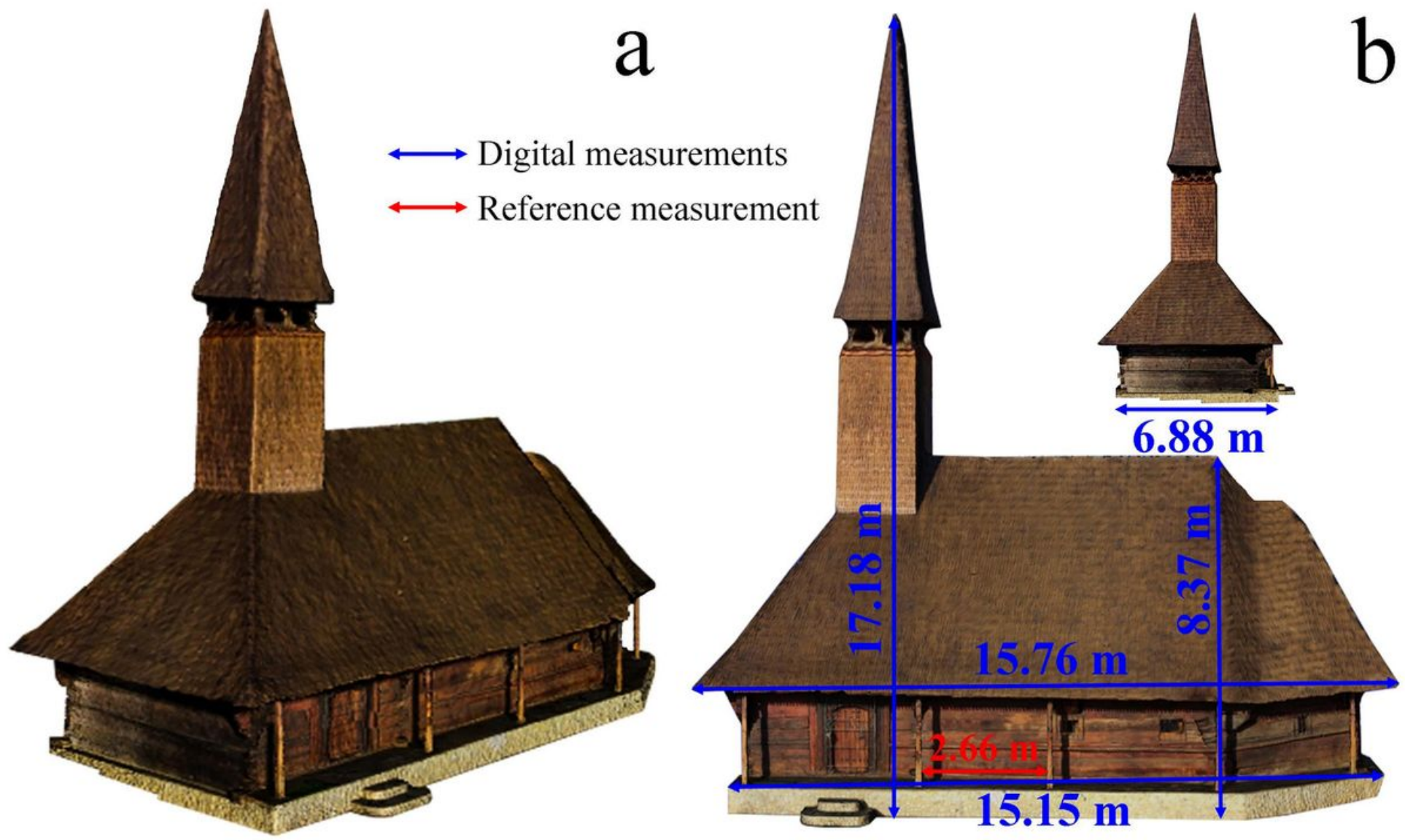
Figure 12

3D model of the wooden church "Saints Archangel Michael and Gabriel" a.The overview of the model;

b.The dimensions of the monument calculated based on the model obtained

\section{Supplementary Files}

This is a list of supplementary files associated with this preprint. Click to download.

- MANUSCRIPTSSUBMISSIONDECLARATION.pdf 